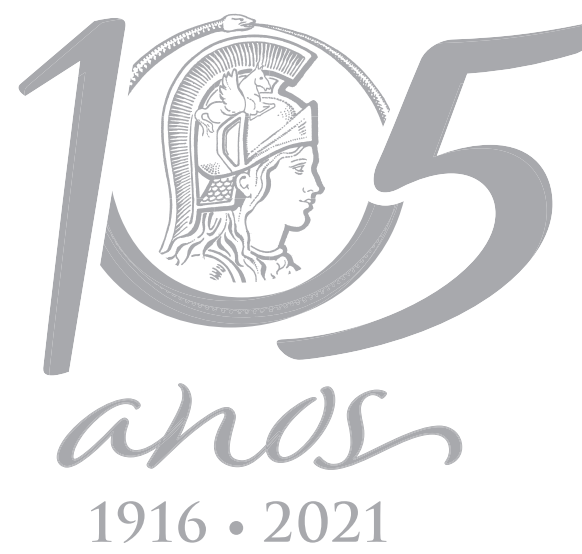

\title{
MICROBIOLOGY
}

\section{Chemotaxonomic characterization of the key genera of diatoms in the Northern Antarctic Peninsula}

\author{
RAUL RODRIGO COSTA, CARLOS RAFAEL B. MENDES, MÁRCIO S. DE SOUZA, \\ VIRGINIA MARIA TAVANO \& EDUARDO R. SECCHI
}

\begin{abstract}
Diatoms are successful in occupying a wide range of ecological niches and biomes along the global ocean. Although there is a recognized importance of diatoms for the Southern Ocean ecosystems and biogeochemical cycles, the current knowledge on their ecology and distribution along the impacted Antarctic coastal regions remains generalized at best. HPLC-CHEMTAX approaches have been extensively used to this purpose, providing valuable information about the whole phytoplankton community, even for those small-size species which are normally difficult to identify by light microscopy. Despite that, the chemotaxonomic method has reserved minimal focus on great diversity of types associated with diatom genera or species. Here, we show a coupling between the key genera and the corresponding chemotaxonomic subgroup type-A or type-B of diatoms via HPLC-CHEMTAX and microscopic analysis, using chlorophyll- $c_{1}$ and chlorophyll- $C_{3}$ as biomarker pigments, respectively. The results demonstrated strong correlations for nine of the fifteen most abundant diatom genera observed along the Northern Antarctic Peninsula, from which five (four) were statistically associated with chlorophyll $-c_{1}$ (chlorophyll $-c_{3}$ ). Our study highlights the importance to observe diatoms in greater detail, beyond being only one functional group, for a better understanding on their responses under a climate change scenario.
\end{abstract}

Key words: Southern Ocean, phytoplankton, diatoms, HPLC-CHEMTAX, microscopy.

\section{INTRODUCTION}

Most of the excess energy stored in the climate system due to anthropogenic greenhouse gas emissions has been absorbed by the oceans (Stocker 2015, Zanna et al. 2018). Covering 30\% of the global ocean's surface, the Southern Ocean has been pointed out to account for up to $75 \%$ of the heat uptake by the oceans over the past century (Frölicher et al. 2015). In addition, it is also responsible by nearly half of the oceanic $\mathrm{CO}_{2}$ uptake (Takahashi et al. 2012), mainly associated with its high seasonal phytoplankton production, indicated as a critical factor in driving oceanic $\mathrm{CO}_{2}$ uptake during the austral summer
(Brown et al. 2019, Costa et al. 2020, Monteiro et al. 2020). Due to progressive southward warming, however, shifts in the distribution of polar species have been observed in Antarctic coastal regions experiencing strong physical alterations (Ducklow et al. 2007, Schofield et al. 2010), especially at the base of the food web in marine ecosystems (Montes-Hugo et al. 2009), which may be impacting the fundamental role of the Southern Ocean on the Earth's energy balance and global biogeochemical cycles.

The Northern Antarctic Peninsula (NAP), which encompasses the Gerlache and Bransfield Straits, the southernmost sector of the Drake Passage, and the northwestern Weddell Sea, is 
a good example of how environmental changes can alter and transform the polar ecosystem through time (Kerr et al. 2018). The NAP marine ecosystem has experienced substantial physical changes due to long-term increases in atmospheric and oceanic temperatures (Henley et al. 2019, Ferreira et al. 2020). Marine glaciers are retreating (Cook et al. 2005, 2016), and the sea ice season has been shortened (Stammerjohn et al. 2008). These long-term physical changes have led to shifts in phytoplankton community composition, potentially threatening trophic structure and biological carbon pump in the local ecosystems (Costa et al. 2020, Ferreira et al. 2020). Diatoms, considered the core base of the Southern Ocean food web (Armbrust 2009, Rousseaux \& Gregg 2014), have been replaced by small flagellate cryptophytes (Montes-Hugo et al. 2009, Mendes et al. 2018a, b). Nonetheless, the critical factors, which are hampering the diatom blooms development during the austral summer along the NAP, as well as in other impacted Antarctic coastal waters, remain an open question (Henley et al. 2019, Costa et al. 2020, Pan et al. 2020).

The study of phytoplankton along the NAP has started more than forty years ago (Ferreira et al. 2020). Since then, different methodological approaches have been adopted to measure the biomass and community composition of these microalgae (e.g., Holm-Hansen \& Mitchell 1991, Rodriguez et al. 2002, Varela et al. 2002, Mendes et al. 2012, Costa et al. 2020). Among them, the chemotaxonomic (HPLC-CHEMTAX) approach has been extensively used in the NAP phytoplankton studies (Rodriguez et al. 2002, Mendes et al. 2012, 2013, 2018a, 2018b, Costa et al. 2020, Pan et al. 2020). This approach based on the chemical taxonomy (CHEMTAX) software uses a factor analysis and steepest descent algorithm to best fit the pigment data onto an initial matrix of pigment ratios, providing valuable information about the whole phytoplankton community, even for those small-size species which are normally difficult to identify by light microscopy. As a result, the CHEMTAX initial matrix ratios based on class-specific accessory pigments and chlorophyll-a (Chl-a) have been modified and improved though time (Rodriguez et al. 2002, Kozlowski et al. 2011, Mendes et al. 2012, 2018b, Costa et al. 2020). Recently applied for the NAP, a separation for the functional group of diatoms has been proposed due to their great diversity of types, which has resulted in two chemotaxonomic subgroups: diatoms type-A and diatoms type-B, identified through chlorophyll- $C_{1}$ and chlorophyll- $c_{3}$, respectively (Costa et al. 2020). However, despite this improvement, results from the chemotaxonomic subgroups have not been simultaneously correlated with measurements of diatom genera or species through microscope identification.

Diatoms are successful in occupying a wide range of ecological niches and biomes along the global ocean, mostly due to their great diversity in morphology and physiology (Malviya et al. 2016, Tréguer et al. 2017). Indeed, a great number of diatom genera and species has been recorded along the Antarctic Peninsula coastal waters (Annett et al. 2010), distributed over a large range of salinity and temperature (Schofield et al. 2017, Brown et al. 2019). Although there is a recognized importance of diatoms for the Southern Ocean ecosystems and biogeochemical cycles, the current knowledge on their ecology and distribution along the impacted Antarctic coastal regions remains generalized at best (Schofield et al. 2017, Henley et al. 2019). Most previous studies have been limited to a taxonomic (microscopic identification) or chemotaxonomic approach and/or with minimal focus on types of diatoms based on CHEMTAX. Here, we show a coupling between the key genera and the corresponding chemotaxonomic subgroup of 
diatoms. Furthermore, we assess the distribution patterns of the two types of diatoms using both chemotaxonomic and taxonomic dataset, which encompass seasonal succession periods (November-March) collected during eight cruises (between 2013-2016) along the NAP. Our study provides a baseline to the use of an initial matrix of pigment ratios to be applied to further phytoplankton ecology research, particularly diatom chemotaxonomic studies across the NAP, as well as in other Antarctic regions. A thorough analysis of major diatom genera/species with their pigment suite may help to disentangle the large range of hydrography features associated with diatom distribution.

\section{MATERIALS AND METHODS}

\section{Study area and sample collection}

Data for this study were collected during eight cruises conducted on board the RV Almirante Maximiano of the Brazilian Navy during the late spring and summer months (November, January, February, and March, respectively) between 2013 and 2016 along the NAP. The study area covered the Gerlache Strait, which separates the Anvers and Brabant Islands from the Antarctic Peninsula; Bransfield Strait, located between the Southern Shetland Islands and the Peninsula; and regions located near the Elephant Island (Fig. 1). February 2015 was sampled across the

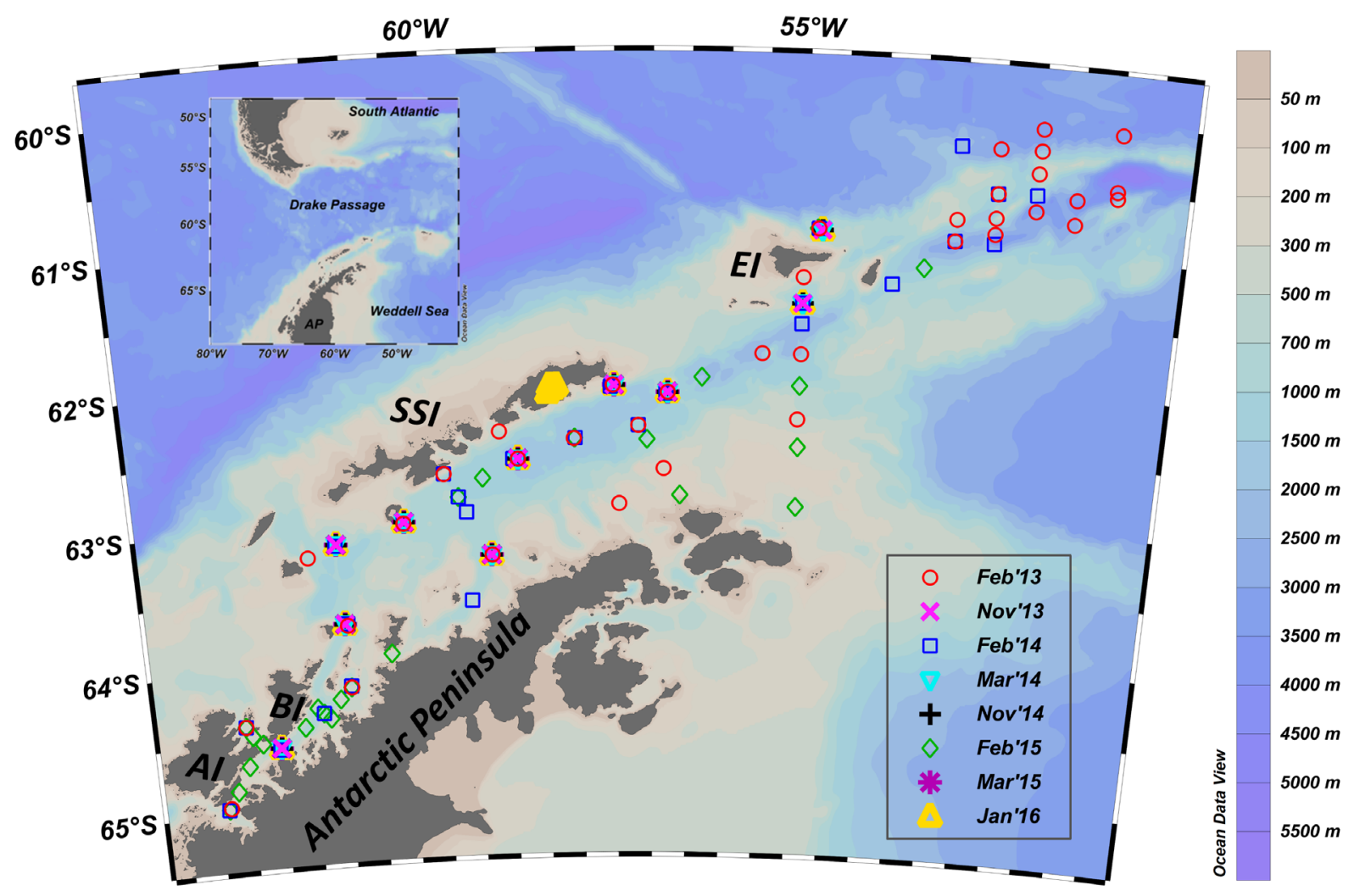

Figure 1. Study area and stations' locations sampled during the late spring and summer months (November, January, February, and March) between 2013 and 2016 along the NAP. The bathymetry is represented by the color scale bar on the right. An inset map in the upper left corner shows a larger area that pinpoints where the main map is located. An inset legend in the lower right corner shows symbols for January (Jan'16), February (Feb'13, Feb'14, and Feb'15), March (Mar'14 and Mar'15), and November (Nov'13 and Nov'14) months. The abbreviations are as follows: Anvers Island (AI), Brabant Island (BI), South Shetland Islands (SSI), Elephant Island (EI), and Antarctic Peninsula (AP). 
Gerlache and Bransfield Straits. In addition to Gerlache and Bransfield Straits, samples in February 2013 and February 2014 were also collected in the northwestern Weddell Sea, located near the tip of the Antarctic Peninsula, with the Clarence Island to the southwest, the Powell Basin/Weddell Sea to the southeast, and the Scotia Sea to the north (Mendes et al. 2018a). The November (2013 and 2014), January (2016) and March (2014 and 2015) months were sampled from the north of the Gerlache Strait to the northeast of the Bransfield Strait (along the South Shetland Islands). Moreover, additional samples were collected within the Admiralty Bay during January 2016 (see Fig. 1).

The discrete seawater samples were collected using a combined Sea-Bird CTD (conductivity-temperature-depth instrument)/ Carrousel $911+$ system ${ }^{\circledast}$ equipped with 24 fivelitre Niskin bottles. Surface seawater samples (5 $m$ depth) were taken in all stations for analyses of phytoplankton pigments and microscopy (Fig. 1).

\section{Microscopic analysis}

The samples collected to the microscopic analysis were preserved in amber glass flasks ( \pm $250 \mathrm{~mL}$ ) with $2 \%$ alkaline Lugol's iodine solution in order to evaluate the species composition and cell concentrations of the phytoplankton assemblage. Settling chambers $(2,10$ or $50-\mathrm{mL}$ settling volume) were inspected on an Axiovert 135 ZEISS inverted microscopic (Utermöhl 1958, Sournia 1978) at 100x, 200x, and 400x magnification, following previous literature (e.g., Lund et al. 1958). Species-specific cell biovolumes were estimated by measuring cell dimensions (such as length, width and height) and applying respective similar geometric shapes (Hillebrand et al. 1999). Carbon biomass ( $\left.\mu g C . L^{-1}\right)$ was obtained from the biovolume values through a carbon to volume ratio used for diatoms (Menden-Deuer \& Lessard 2000). The most abundant diatom genera were selected for cell carbon biomass calculation; that is, those genera that were identified in at least $10 \%$ of the samples counting via microscopic analysis (Fig. 2), as a significant statistical number of data was needed for making reasonable correlations with the results of HPLC-CHEMTAX analysis. Additionally, diatom family Naviculaceae was also considered in the analysis.

\section{HPLC analysis}

For phytoplankton pigment analysis, seawater samples $(0.5-2.5 \mathrm{~L})$ were filtered under low vacuum through GF/F filters, which were subsequently frozen in liquid nitrogen for later HPLC pigment analysis. In the laboratory, the filters were placed in a screw-cap centrifuge tube with $3 \mathrm{~mL}$ of $95 \%$ cold-buffered methanol (2\% ammonium acetate) containing $0.05 \mathrm{mg}$ $\mathrm{L}^{-1}$ trans- $\beta$-apo-8'-carotenal (Fluka) as internal standard. Samples were sonicated for $5 \mathrm{~min}$ in an ice-water bath, placed at $-20^{\circ} \mathrm{C}$ for $1 \mathrm{~h}$, and then centrifuged at $1100 \mathrm{~g}$ for $5 \mathrm{~min}$ at $3^{\circ} \mathrm{C}$. The supernatants were filtered through Fluoropore PTFE membrane filters ( $0.2 \mu \mathrm{m}$ pore size) to separate the extract from remains of filter and cell debris. Immediately prior to injection, 1000 $\mu \mathrm{L}$ of sample was mixed with $400 \mu \mathrm{L}$ of Milli-Q water in $2.0 \mathrm{~mL}$ amber glass sample vials, which then were placed in the HPLC cooling rack $\left(4^{\circ} \mathrm{C}\right)$. The pigment extracts were analysed using a Shimadzu HPLC constituted by a solvent distributor module (LC-20AD) with a control system (CBM-20A), a photodiode detector (SPDM20A), and a fluorescence detector (RF$10 A X L)$. The chromatographic separation of the pigments was performed using a monomeric C8 column (SunFire; $15 \mathrm{~cm}$ long; $4.6 \mathrm{~mm}$ in diameter; $3.5 \mu \mathrm{m}$ particle size) at a constant temperature of $25^{\circ} \mathrm{C}$. The mobile phase (solvent) and respective gradient followed the method developed by 

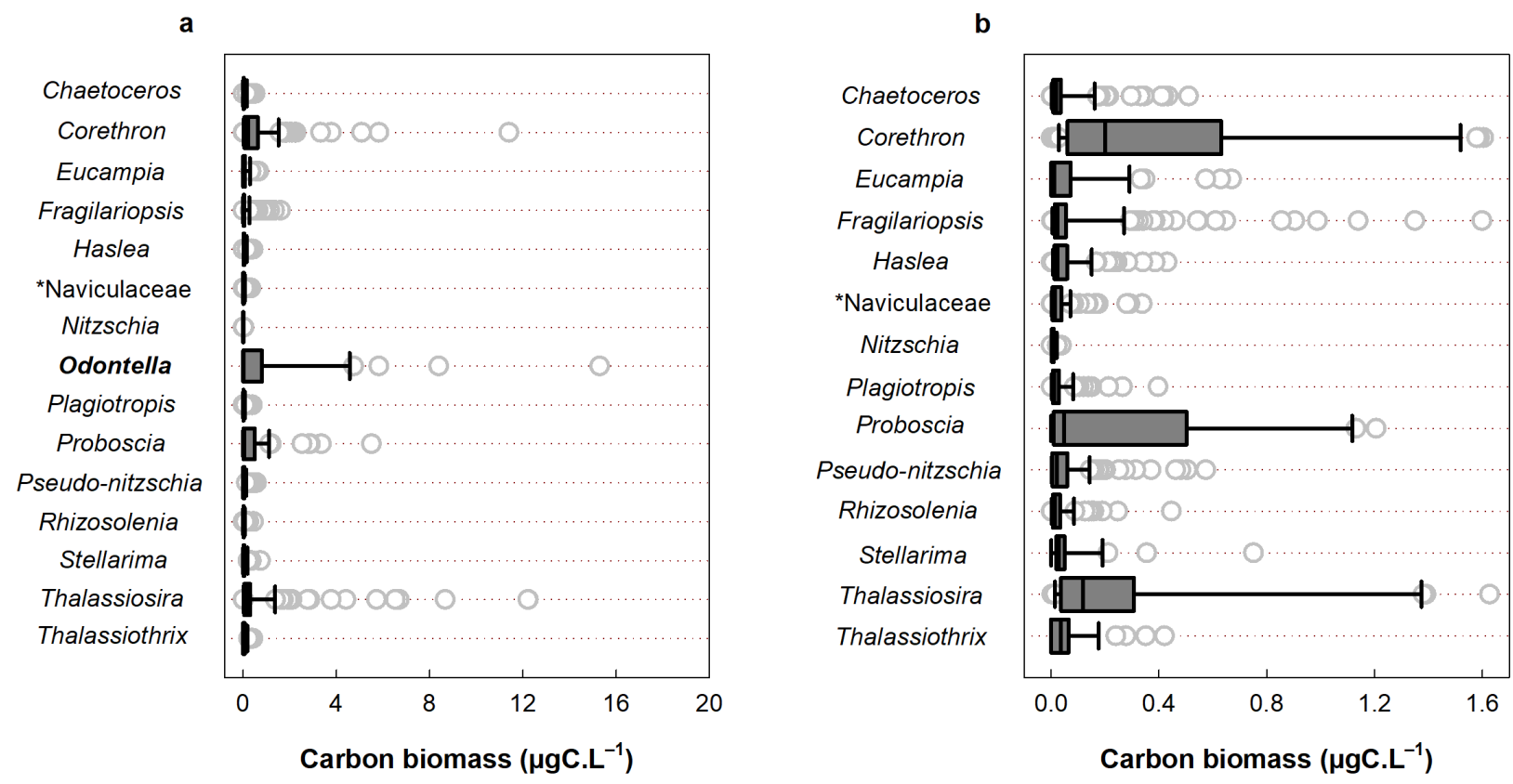

Figure 2. Carbon biomass values ( $\left.\mu \mathrm{gC} . \mathrm{L}^{-1}\right)$ of the most abundant diatom genera (a), and stretched carbon biomass scale (b). The vertical lines of the boxes indicate the median and the 25th and 75th percentiles. The light gray open circles indicate the outliers. The whiskers extend to values not considered as outliers. Diatom genus Odontella was taken in bold to highlight its carbon biomass values with respect to the other genera. The asterisk ${ }^{*}$ ) indicates the diatom family Naviculaceae, the only one exception in our grouping of analysis based on diatom genera.

Zapata et al. (2000), which was discussed and optimized by Mendes et al. (2007), with a flow rate of $1 \mathrm{~mL} \mathrm{~min}{ }^{-1}$, injection volume of $100 \mu \mathrm{L}$, and 40 min runs. All the studied pigments were identified from both absorbance spectra and retention times, and the concentrations were calculated from the signals in the photodiode array detector in comparison with commercial standards obtained from DHI (Institute for Water and Environment, Denmark). Peaks were integrated using LC-Solution software, and all of the peak integrations were checked manually and corrected when necessary. A quality assurance threshold procedure, through application of quantification limit (LOQ) and detection limit (LOD), was applied to the pigment data (Hooker et al. 2005) to reduce the uncertainty of pigments found in low concentrations. The LOQ and LOD procedures were performed according to Mendes et al. (2007). In order to correct for losses and volume changes, the concentrations of the pigments were normalized to the internal standard.

\section{CHEMTAX ANALYSIS}

The absolute and relative contribution of phytoplankton groups to the overall biomass were calculated from the class-specific accessory pigments and total Chl-a using the chemical taxonomy (CHEMTAX) software v1.95 (Mackey et al. 1996). The basis for calculations and procedures are fully described by Mendes et al. (2018a). Although Chl-a concentration is not an absolute measure of algal biomass, such as carbon, it can be used as a proxy for biomass (Jeffrey et al. 1997, Huot et al. 2007), as this photosynthetic pigment is common to all autotrophic phytoplankton species. Therefore, here we use the term Chl-a referring to either 
absolute biomass or relative biomass attributed to the corresponding chemotaxonomic groups (Mendes et al. 2012, 2013, 2018a, 2018b, Costa et al. 2020).

In this study, we applied two different initial matrices of pigment ratios to CHEMTAX (Supplementary Material - Tables SI and SII), which gave rise to two independent methodological approaches: "Method A" and "Method B". In the Method A, seven algal groups were chosen: diatoms type-A, diatoms type-B, dinoflagellates type-A, dinoflagellates type-B, haptophytes type 8 (Phaeocystis antarctica), cryptophytes, and green flagellates. In this method, the initial matrix of pigment ratios was based on three biomarker pigments (fucoxanthin, chlorophyll- $c_{1}$ and chlorophyll- $c_{3}$ ) to estimate total diatom biomass (sum of biomass of diatoms type-A and diatoms type-B). Fucoxanthin and chlorophyll- $C_{1}\left(\mathrm{Chl}-\mathrm{C}_{1}\right)$ were used as biomarkers of diatoms type- $A$, and fucoxanthin and chlorophyll- $\mathrm{C}_{3}\left(\mathrm{Chl}-\mathrm{C}_{3}\right)$ as biomarkers of diatoms type-B (Table SI). On the other hand, in the Method $B$, the initial matrix of pigment ratios was based on only one biomarker pigment (the fucoxanthin) to estimate total diatom biomass (Table SII). We applied both methods to investigate potential differences in the determination of diatom biomass, that is, over- or underestimation, assessing how much concentration of $\mathrm{Chl}-\mathrm{C}_{1}$ and $\mathrm{Chl}-\mathrm{C}_{3}$ influences in estimation of diatom chemotaxonomic subgroups. The carbon biomass of the identified diatom genera via microscopic analysis was used as a baseline to assess a potential difference between both Methods.

For optimization of the input matrix, series of 60 pigment ratio matrices were generated by multiplying each ratio from the initial matrix by a random function as described in Wright et al. (2009). The averages of the best six (10\%) output matrices, with the lowest residual or mean square root error, were taken as the optimized results. The optimization of the input matrix was performed separately to each one of the eight performed oceanographic cruises, allowing to assess variations in pigment: Chl-a ratios, due to potential differences in light availability between years (Schlüter el al. 2000, Higgins et al. 2011). In addition, these procedures were performed separately to the two distinct initial matrices of pigment ratios, i.e., to the Methods $A$ and $\mathrm{B}$. The CHEMTAX derived results of diatoms were quality-controlled by microscopic analysis.

\section{Statistical analysis}

Given that there is a relationship between cell size and chlorophyll concentrations in diatoms (Stauber \& Jeffrey 1988, Montagnes et al. 1994), we correlated the carbon biomass values of the most abundant diatom genera (Fig. 2) with $\mathrm{Chl}^{-\mathrm{C}_{1}}$ and $\mathrm{Chl}_{-} \mathrm{C}_{3}$ of our dataset to determine their chemotaxonomic subgroups type-A or type-B (Figs. 3 and 4), which were estimated via HPLCCHEMTAX analysis. Data were excluded from analysis whenever the concentration of either Chl- $c_{1}$ or Chl- $C_{3}$ was zero or missing, and / or carbon biomass value was zero or missing. This qualitycontrol step was performed to each diatom genus. It was considered significant relationship between carbon biomass and $\mathrm{Chl}-\mathrm{C}_{1}$ or $\mathrm{Chl}-\mathrm{C}_{3}$, those genera that the slope significance level (that is, the $\mathrm{Chl}-\mathrm{C}_{1}$ or $\mathrm{Chl}-\mathrm{C}_{3}$ to carbon ratio) was $p<0.0001$ (Figs. 3 and 4). This $p$-value threshold minimizes an artefact possibility on correlations of the parameters. To support the relationship between diatom genera and their respective chemotaxonomic subgroups, we summed all carbon biomass of diatom genera according to the identified chemotaxonomic subgroup (that is, type-A or type-B), and compared it with respective diatom-type biomass, estimated via HPLC-CHEMTAX analysis ( $\mathrm{mg} \mathrm{m}^{-3}$ of Chl-a; Supplementary Material - Figure S1). Furthermore, we also assessed differences between Methods $A$ and $B$, comparing them with respect to the total sum of carbon biomass associated with the identified diatom genera (Fig. S2). 

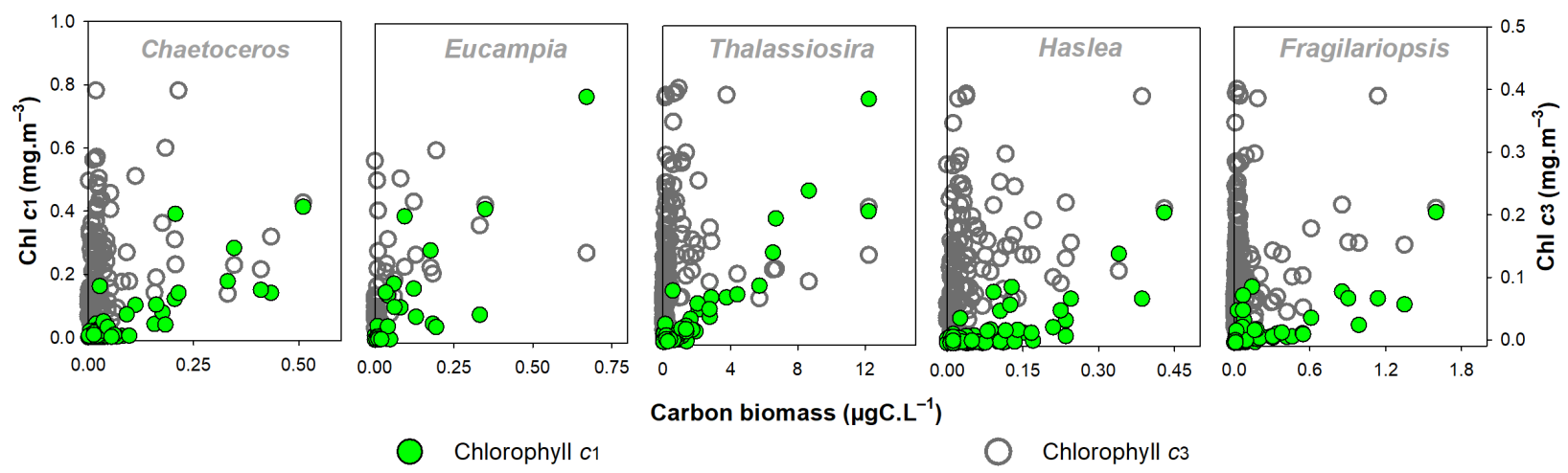

Figure 3. Relationships between carbon biomass values $\left(\mu \mathrm{gC} . \mathrm{L}^{-1}\right)$ of diatom genera and chlorophyll- $c_{1}\left(\mathrm{Chl}-c_{1} ;\right.$ mg. $\left.\mathrm{m}^{-3}\right)$, represented by green circles. Chaetoceros $\left(R^{2}: 0.68 ; p<0.0001 ; n: 116\right)$, Eucampia $\left(R^{2}: 0.70 ; p<0.0001 ; n: 32\right)$, Thalassiosira $\left(R^{2}: 0.90 ; p<0.0001 ; n: 170\right)$, Haslea $\left(R^{2}: 0.60 ; p<0.0001 ; n: 110\right)$, and Fragilariopsis $\left(R^{2}: 0.57 ; p<0.0001\right.$; $n: 166)$. Chlorophyll- $c_{3}\left(\mathrm{Chl}-c_{3} ; \mathrm{mg} \cdot \mathrm{m}^{-3}\right)$ is represented by gray open circles at background.

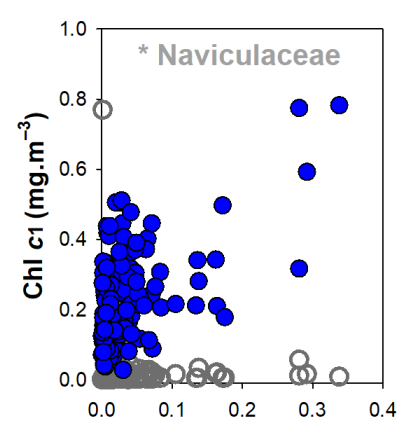

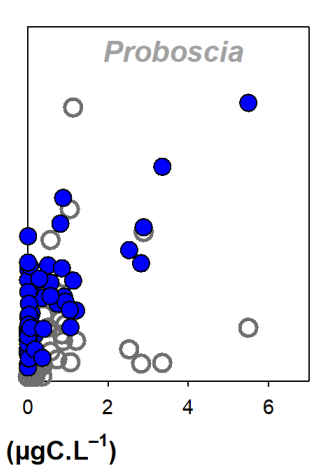

Carbon biomass $\left(\mu \mathrm{gC} . \mathrm{L}^{-1}\right)$

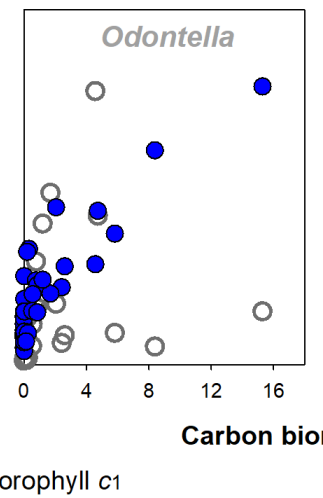

Chlorophyll $c 1$

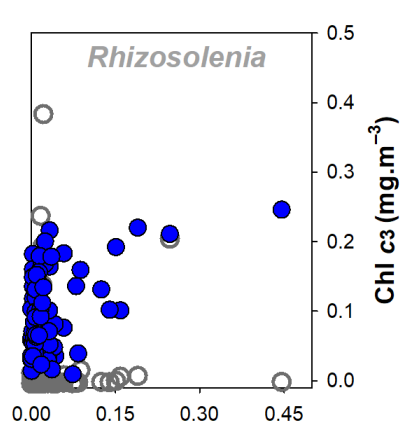

Figure 4. Relationships between carbon biomass values $\left(\mu \mathrm{gC} . \mathrm{L}^{-1}\right)$ of diatom genera and chlorophyll $-c_{3}\left(\mathrm{Chl}-c_{3}\right.$; mg. $\left.\mathrm{m}^{-3}\right)$, represented by blue circles. Naviculaceae $\left(R^{2}: 0.33 ; p<0.0001 ; n: 159\right)$, Odontella $\left(R^{2}: 0.78 ; p<0.0001 ; n: 27\right)$, Proboscia ( $\left.R^{2}: 0.56 ; p<0.0001 ; n: 60\right)$, and Rhizosolenia $\left(R^{2}: 0.20 ; p<0.0001 ; n: 85\right)$. Chlorophyll- $c_{1}\left(C h l-c_{1} ; m g \cdot m^{-3}\right)$ is represented by gray open circles at background. The asterisk $\left(^{*}\right)$ indicates the diatom family Naviculaceae, the only one exception in our grouping of analysis based on diatom genera.

\section{RESULTS}

The main identified and counted diatom genera via inverted microscope analysis are shown in Fig. 2. Standing out among diatom genera, much due to its large cell size, the genus Odontella showed higher carbon biomass values when compared with the others (Fig. 2a). In the stretched carbon biomass scale of Fig. 2b, excluding the genus Odontella, was possible to observe a wide distribution of diatom genera contributing with relatively high values of carbon biomass (Fig. $2 b)$.
There was a large variability in mean surface values of Chl-a between the sampling periods. The highest mean Chl-a value was reported during January2016, whereas the lowest value was found in November 2013 (Table I). Fucoxanthin was the second most abundant pigment. Its highest mean value was also reported during January 2016, whereas the lowest occurred in

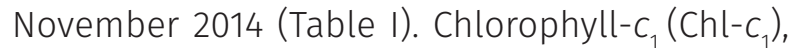
chlorophyll- $\mathrm{C}_{2}\left(\mathrm{Chl}-\mathrm{C}_{2}\right)$, and chlorophyll $-\mathrm{C}_{3}\left(\mathrm{Chl}-\mathrm{C}_{3}\right)$ showed similar patterns, although the highest mean Chl-C c $_{3}$ alue was found in March 2015, which contrasted with the highest values of 
Table I. Average concentrations $\left(\mathrm{mg} \cdot \mathrm{m}^{-3}\right)$ of chlorophyll-a $(\mathrm{Chl}-a)$, chlorophyll- $c_{1}\left(\mathrm{Chl}-\mathrm{c}_{1}\right)$, chlorophyll- $c_{2}\left(\mathrm{Chl}-\mathrm{c}_{2}\right)$, chlorophyll- $\mathrm{c}_{3}$ ( $\mathrm{Chl}-\mathrm{C}_{3}$ ), fucoxanthin (Fuco), and the sum of all other pigments during the late spring and summer months (November, January, February, and March) between 2013 and 2016 along the NAP. Standard deviation is showed in parentheses. Other pigments are represented as a sum of 19'-hexanoyloxyfucoxanthin, gyroxanthin diester, prasinoxanthin, peridinin, alloxanthin, chlorophyll $b$, 19'-butanoyloxyfucoxanthin, 19'-hexanoyloxy-4ketofucoxanthin, and $\mathrm{Chl} c_{2}$-monogalactosyldiacylglycerol ester.

\begin{tabular}{|c|c|c|c|c|c|c|}
\hline $\mathrm{mg} \cdot \mathrm{m}^{-3}$ & Chl a & Chl c1 & Chl c2 & Chl c3 & Fuco & Other pigments \\
\hline February 2013 (n=39) & $1.25(0.48)$ & $0.006(0.01)$ & $0.19(0.07)$ & $0.13(0.07)$ & $0.42(0.29)$ & $0.38(0.16)$ \\
\hline November $2013(n=18)$ & $0.75(0.77)$ & $0.001(0.004)$ & $0.09(0.10)$ & $0.06(0.06)$ & $0.30(0.42)$ & $0.13(0.04)$ \\
\hline February $2014(n=34)$ & $1.35(0.60)$ & $0.008(0.01)$ & $0.22(0.10)$ & $0.1(0.05)$ & $0.39(0.27)$ & $0.42(0.17)$ \\
\hline March $2014(n=10)$ & $1.60(1.27)$ & $0.02(0.03)$ & $0.19(0.13)$ & $0.09(0.06)$ & $0.68(0.68)$ & $0.22(0.12)$ \\
\hline November $2014(n=19)$ & $0.94(0.32)$ & $0.001(0.001)$ & $0.11(0.05)$ & $0.05(0.02)$ & $0.27(0.09)$ & $0.25(0.10)$ \\
\hline February $2015(n=41)$ & $1.35(0.88)$ & $0.009(0.01)$ & $0.22(0.16)$ & $0.13(0.11)$ & $0.57(0.46)$ & $0.31(0.18)$ \\
\hline March $2015(n=10)$ & $1.9(0.79)$ & $0.01(0.02)$ & $0.28(0.13)$ & $0.19(0.09)$ & $1.02(0.46)$ & $0.28(0.10)$ \\
\hline January $2016(n=25)$ & $5.8(4.59)$ & $0.15(0.19)$ & $1.23(0.95)$ & $0.13(0.08)$ & $3.14(2.50)$ & $0.26(0.16)$ \\
\hline
\end{tabular}

Chl- $C_{1}$ and Chl- $c_{2}$ recorded in January 2016. The sum of other pigments showed the highest value during February 2014 (Table I). In general, the chlorophylls-c (Chls-c) and the sum of other pigments showed the lowest values in November months (Table I).

Although the determination coefficient $\left(R^{2}: 0.68,0.70,0.90,0.60\right.$, and 0.57$)$ varied with the diatom genera, there were significant relationships $(p<0.0001)$ between $\mathrm{ChL}_{-} \mathrm{C}_{1}$ (indicative ofdiatoms type-A)and carbon biomass values of Chaetoceros, Eucampia, Thalassiosira, Haslea, and Fragilariopsis, respectively (Fig. 3). Regarding the $\mathrm{Chl}_{-} \mathrm{C}_{3}$ (indicative of diatoms type-B), there were significant relationships $(p<0.0001)$ with carbon biomass values of the Naviculaceae, Odontella, Proboscia, and Rhizosolenia, with $\mathrm{R}^{2}$ of $0.33,0.78,0.56$, and 0.20 , respectively (Fig. 4). In contrast, there were no statistical relationships between these two biomarker pigments with Corethron, Nitzschia, Pseudo-nitzschia, Stellarima, Plagiotropis, and Thalassiothrix (Fig. S3). In addition, there was a strong statistical relationship between the diatoms type-A biomass and their respective carbon biomass (as the sum of carbon biomass values of Chaetoceros, Eucampia, Thalassiosira, Haslea, and Fragilariopsis) (Fig. S1). Likewise, there was also a strong statistical relationship between the diatoms type-B biomass and their respective carbon biomass (as the sum of carbon biomass values of Naviculaceae, Odontella, Proboscia, and Rhizosolenia) (Fig. S1).

The applied Methods showed a strong statistical relationship with each other through their estimated diatom absolute concentrations $\left(R^{2}: 0.99, p<0.0001\right)$. Further, when compared with carbon biomass measurements, both methods showed strong correlations (see Fig. S2). The chemotaxonomic subgroups of diatoms showed a large interannual variability of relative biomass along the sampled months (Fig. 5). The diatoms type-B proportion to the total Chl-a was almost always higher than diatoms type-A proportion, with exception of February 2014 (Fig. 5). An interannual variability was also observed 


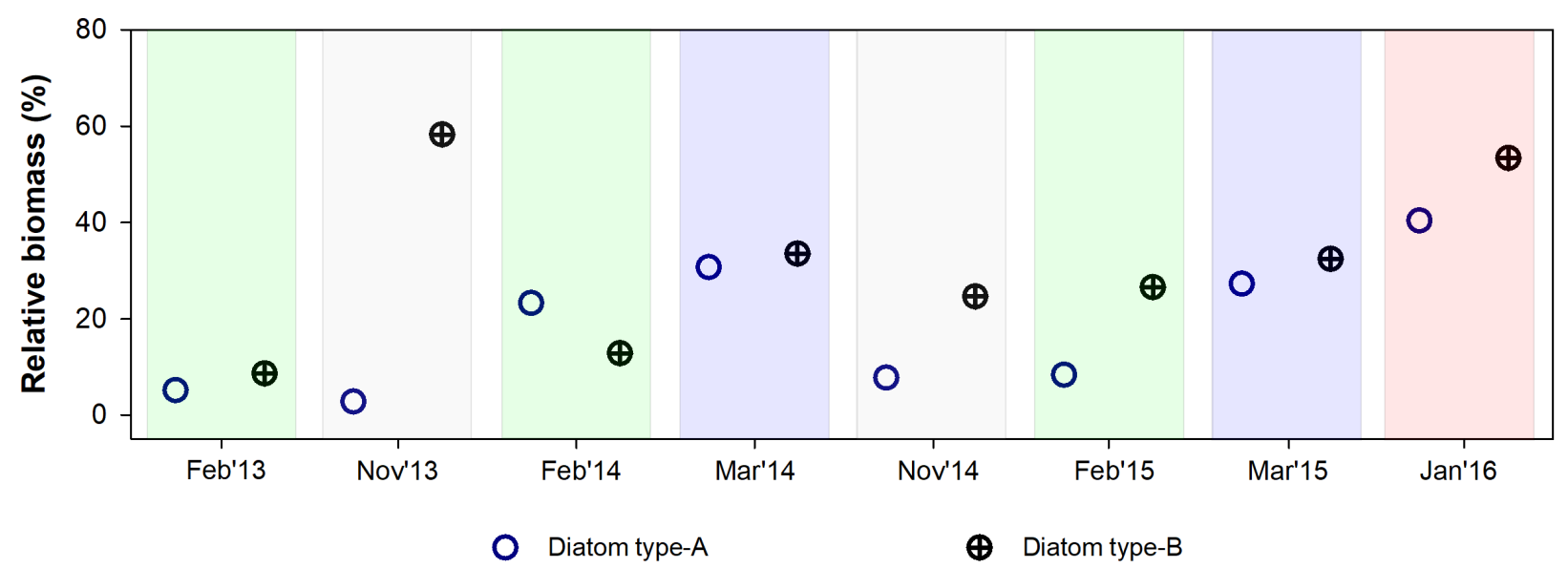

Figure 5. Average relative biomass (\%; to the total $\mathrm{Chl}-\mathrm{a}$ ) of the chemotaxonomic subgroups type-A (dark blue open circles) and type-B (black crossed circles) of diatoms during the late spring and summer months (November, January, February, and March) between 2013 and 2016 along the NAP. The background gray, red, green, and blue shades highlight the months of November, January, February, and March, respectively.

on diatom genera, where the ones assigned as type-A, as well as Odontella and Proboscia, showed the highest carbon biomass associated with January 2016 (see Tables SIII and SIV). On the other hand, Naviculaceae and Rhizosolenia showed the highest carbon biomass during March 2015 (Table SIV). In general, there was no marked seasonal pattern on these diatom genera (Tables SIII and SIV).

\section{DISCUSSION}

It is estimated that diatoms are responsible for about $40 \%$ of marine primary productivity, and particulate carbon exported to depth as part of the biological pump (Tréguer et al. 2017). For this reason, considering that global ocean covers about $70 \%$ of the Earth's surface, diatoms can be considered as a key group among the autotrophic organisms, playing crucial functions in trophic structure and biogeochemical cycles (Assmy et al. 2013, Costa et al. 2020). The ecological success of diatoms is strongly associated with their pigment profile, composed by photosynthetic and photoprotector pigments, which in general include Chl-a, Chls-c, fucoxanthin and some other carotenoids (Stauber \& Jeffrey 1988). Chlorophylls and fucoxanthin are photosynthetic pigments responsible by photosynthesis activity, whereas $\beta$-carotene, diadinoxanthin, and diatoxanthin are associated with photoprotection mechanisms to cope with light intensity fluctuations in marine ecosystems (van Leeuwe et al. 2005, Araujo et al. 2017). In diatoms, as in all phototrophic phytoplankton species, the Chl-a plays a central role in photochemical energy conversion, while Chls-c and fucoxanthin are accessory pigments responsible to efficiently rise photon accumulation through different absorption maxima (Kuczynska et al. 2015).

The Chls-c cover a family of chlorophylls mainly comprising $\mathrm{Chl}-\mathrm{C}_{1}, \mathrm{Chl}-\mathrm{C}_{2^{\prime}}$ and $\mathrm{Chl}-\mathrm{C}_{3^{\prime}}$ all of which serve exclusively as an antenna pigment (Kuczynska et al. 2015). Stauber \& Jeffrey (1988), through analyses of the photosynthetic pigments of 51 species (28 genera) of tropical and sub-tropical diatoms, depicted that $88 \%$ of the diatoms tested have shown $\mathrm{Chl}-\mathrm{C}_{2}$ together with $\mathrm{Chl}-\mathrm{C}_{1}$. The authors have still shown that when Chl- $c_{1}$ was absent or in trace amounts (8 species, 3 genera) it was replaced by $\mathrm{ChL}^{-} \mathrm{C}_{3}$, having only one exception of a species containing approximately equal amounts of the three Chls-c. 
These results, which were further investigated (e.g., Zapata et al. 2011), have provided a base to diatom type separation, applied latter to HPLC/ CHEMTAX analysis (Higgins et al. 2011, Rozema et al. 2017, Costa et al. 2020). Therefore, from among different forms of Chls-c described to diatoms, the most abundant are thought to be Chl- $c_{1}$ and Chl- $c_{2}$ (Kuczynska et al. 2015), which contrasts with our results. Here, $\mathrm{Chl}-\mathrm{c}_{3}$ was predominantly higher than $\mathrm{Chl}-\mathrm{C}_{1}$ (Table I). This could be explained by the fact that $\mathrm{Chl}-\mathrm{C}_{3}$ is an ambiguous biomarker pigment also present in haptophytes and dinoflagellates type-B, unlike Chl- $c_{1}$ (see Table SI).

We found strong correlations for nine of the fifteen diatom genera, from which five (four) were statistically associated with $\mathrm{Chl}-\mathrm{C}_{1}\left(\mathrm{Chl}-\mathrm{C}_{3}\right)$. The genera of diatoms Chaetoceros, Eucampia, Thalassiosira, Haslea, and Fragilariopsis were classified as diatoms type-A, whereas Naviculaceae, Odontella, Proboscia, and Rhizosolenia were classified as diatoms type-B (see Figs. 3 and 4). Surprisingly, the genus Corethron was correlated neither with $\mathrm{Chl}_{-\mathrm{C}_{1} \text { nor }}$ with $\mathrm{Chl}-\mathrm{C}_{3}$, even showing high carbon biomass values. Pseudo-nitzschia and Nitzschia also did not show statistical relationships with either of these two biomarker pigments (Fig. S3). This could be due to the concomitant presence of Chl- $\mathrm{C}_{1}$ and $\mathrm{Chl}-\mathrm{C}_{3}$ in these genera, such as it has already been observed in the literature (Stauber \& Jeffrey 1988, Zapata et al. 2011). Another critical factor preventing a potential correlation to small pennate or small centric diatom genera, for which a chemotaxonomic subgroup was not ascribed here, would be interference of Chl- $\mathrm{C}_{1}$ or Chl- $\mathrm{C}_{3}$ content of large diatoms of other genera. This latter case becomes evident when we observe that a high correlation with either $\mathrm{Chl}-\mathrm{C}_{1}$ or $\mathrm{Chl}-\mathrm{C}_{3}$ for most of the identified diatom genera is strongly dependent on their high carbon biomass values (see Figs. 2-4).
Furthermore, the diatom genera associated with Chl- $C_{1}$ showed higher $\mathrm{R}^{2}$ than those associated with $\mathrm{Chl}-\mathrm{C}_{3}$. As already mentioned above, this could also be due to the fact that $\mathrm{Chl}_{-} \mathrm{C}_{3}$ is an ambiguous biomarker pigment, which still explains the higher ( 0.2) additive constant (referred to as the $y$-intercept) associated with diatoms assigned as type-B than those pointed out as type-A ( 0) (Figs. 3 and 4).

The strong statistical relationship for both chemotaxonomic subgroups with respect to their respective total carbon biomass values supports that those identified diatom genera are reliably represented (see Fig. S1). Moreover, the significant relationship ( $R^{2}: 0.99 ; p<0.0001$ ) between the Method A and Method B through their estimated diatom absolute concentrations (data not shown), and the also significant relationship that both methods showed in respect to the carbon biomass values (as the total sum of carbon biomass of the identified diatom genera; see Fig. S2), indicate that regardless the applied method the chemotaxonomic estimation of diatom biomass is reliable according to the carbon biomass measurements. These results also support the diatom type separation performed by the Method A.

It has been reported that the chemotaxonomic subgroups of diatoms showed distinct biomass distribution, indicating a possible seasonal pattern between them during spring in the coastal Arctic Ocean (Alou-Font et al. 2013). The authors have found that the reported bloom was dominated by diatoms type-B associated with low snow cover sites and high irradiance, while diatoms type-A were only observed under high snow cover and low irradiance conditions (Alou-Font et al. 2013). Additionally, although no statistical relationships have been performed, this previous study still associated the chemotaxonomic subgroup type-A to the centric diatom genera Chaetoceros 
and Thalassiosira, converging with our analysis (Fig. 3), and type-B with the pennate diatom genera Navicula and Nitzschia. Although we did not get conclusive results on the genus Nitzschia, the genus Navicula, belonging to the family Naviculaceae, also converges with our analysis (Fig. 4). However, despite some similarity with these previous results, in our study there was no marked seasonal pattern associated with chemotaxonomic subgroups of diatoms during four sampled austral summers along the NAP (Fig. 5). Furthermore, our data did not either demonstrate any link between subgroup type-A and centric diatoms, or subgroup type-B and pennate diatoms. Two of five diatom genera assigned as type-A were pennate in our analysis (Haslea and Fragilariopsis; Fig. 3).

In our study, there was a great interannual variability in phytoplankton biomass during the austral summers along the NAP (Table 1). Although fucoxanthin is an ambiguous biomarker pigment, its concentration in other groups is in minor amounts compared with diatoms (Higgins et al. 2011), indicating that high fucoxanthin values recorded in our dataset were likely due to the contributions of diatoms (Table I), associated with their chemotaxonomic subgroups. In general, no patterns were found with chemotaxonomic subgroups of diatoms (Fig. 5), as well as with their correlated genera (Table SIII and SIV). On the contrary, the majority of diatom genera showed their highest carbon biomass contributions during January 2016 (Table SIII and SIV), which points out to an atypical austral summer. In fact, this year was anomalous, triggering a massive bloom of the diatom Odontella weissflogii during the NAP late summer (Costa et al. 2020), as a consequence of the effects of the extreme 2015/2016 El Niño (Costa et al. 2021). Similar to observed in other diatom genera, this great contribution of Odontella weissflogii during February 2016 indicates a large interannual variability in the genus Odontella, as it is demonstrated by its very low carbon biomass values during our observed February (2013-2015) periods along the NAP (see Table SIII and SIV).

Likewise, a considerable interannual variability between diatom species or species groups has also been reported in the phytoplankton community over three austral summers in the Ryder Bay, a small coastal embayment of the West Antarctic Peninsula (Annett et al. 2010). These previous results reinforce that our dataset is not sufficiently large to depict with certainty any pattern associated with diatom genera, and their respective chemotaxonomic subgroups. Despite that, here we identified the key diatom genera and potentially assigned their corresponding chemotaxonomic subgroups, using both taxonomic and HPLC-CHEMTAX approaches. Although no definitive seasonal patterns were found with diatom genera and their corresponding chemotaxonomic subgroups, as Chls-c have differences in the absorption spectrum (Kuczynska et al. 2015), it is likely that the pigment profile difference between diatoms type-A and diatoms type-B may have an ecological implication. For this reason, our study highlights the importance to observe diatoms in greater detail, beyond being only one functional group, and indicates the need for further studies about diatom taxa (including small-size species) along the NAP region. These approaches will allow a better understanding on diatom responses under a climate change scenario.

\section{Acknowledgments}

This is a multidisciplinary study as part of the Brazilian High Latitude Oceanography Group (GOAL) activities in the Brazilian Antarctic Program (PROANTAR). Financial support was provided by Conselho Nacional de Desenvolvimento Científico e Tecnológico (CNPq) and 
Coordenação de Aperfeiçoamento de Pessoal de Nivel Superior (CAPES). This study was conducted within the activities of the INTERBIOTA, NAUTILUS, PROVOCCAR, ECOPELAGOS (CNPq grant numbers 407889/20132, 405869/2013-4, 442628/2018-8, 442637/20187, respectively) and CMAR2 (CAPES grant number 23038.001421/2014-30) projects. The authors thank to the crew of the RV Almirante Maximiano of the Brazilian Navy and several scientists and technicians participating in the cruise for their valuable help during sampling. We are grateful to Simon Wright, from the Australian Antarctic Division, for providing the CHEMTAX v.1.95 software. R.R. Costa, C.R.B. Mendes and E.R. Secchi are granted with research fellowships from CNPq. M. de Souza is granted a PNPD-CAPES fellowship at the Programa de Pós-graduação em Oceanografia Biológica (FURG). CAPES also provided free access to many relevant journals though the portal "Periódicos CAPES". We are thankful for the constructive criticism of the anonymous reviewer, who helped to improve the manuscript. All authors declare they have no conflict of interests.

\section{REFERENCES}

ALOU-FONT E, MUNDY CJ, ROY S, GOSSELIN M \& AGUSTí S. 2013. Snow cover affects ice algal pigment composition in the coastal Arctic Ocean during spring. Mar Ecol Prog Ser 474: 89-104.

ANNETT AL, CARSON DS, CROSTA X, CLARKE A \& GANESHRAM RS. 2010. Seasonal progression of diatom assemblages in surface waters of Ryder Bay, Antarctica. Polar Biol 33: 13-29.

ARAUJO MLV, MENDES CRB, TAVANO VM, GARCIA CAE \& BARINGER MON. 2017. Contrasting patterns of phytoplankton pigments and chemotaxonomic groups along $30^{\circ} \mathrm{S}$ in the subtropical South Atlantic Ocean. Deep- Sea Res Part | 120: 112-121.

ARMBRUST EV. 2009. The life of diatoms in the world's oceans. Nature 459: 185-192.

ASSMY P ET AL. 2013. Thick-shelled, grazer-protected diatoms decouple ocean carbon and silicon cycles in the iron limited Antarctic Circumpolar Current. Proc Natl Acad Sci 110: 20633-20638.

BROWN MS, MUNRO DR, FEEHAN CJ, SWEENEY C, DUCKLOW HW \& SCHOFIELD OM. 2019. Enhanced oceanic CO2 uptake along the rapidly changing West Antarctic Peninsula. Nat Clim Change 9: 678-683.
COOK AJ, HOLLAND PR, MEREDITH MP, MURRAY T, LUCKMAN A \& VAUGHAN DG. 2016. Ocean forcing of glacier retreat in the western Antarctic Peninsula. Science 353: 283-286.

COOK AJ, FOX AJ, VAUGHAN DG \& FERRIGNO JG. 2005. Retreating Glacier Fronts on the Antarctic Peninsula over the Past Half-Century. Science 308: 541-544.

COSTA RR, MENDES CRB, TAVANO VM, DOTTO TS, KERR R, MONTEIRO T, ODEBRECHT C \& SECCHI ER. 2020. Dynamics of an intense diatom bloom in the Northern Antarctic Peninsula, February 2016. Limnol Oceanogr 65: 2056-2075.

COSTA RR, MENDES CRB, FERREIRA A, TAVANO VM, DOTTO TS \& SECCHI ER. 2021. Large diatom bloom off the Antarctic Peninsula during cool conditions associated with 2015/2016 El Niño. Commun Earth Environ 2: 252.

DUCKLOW HW, BAKER K, MARTINSON DG, QUETIN LB, ROSS RM, SMITH RC, STAMMERJOHN SE, VERNET M \& FRASER W. 2007. Marine pelagic ecosystem: The West Antarctic Peninsula. Phil Trans R Soc B Biol Sci 362: 67-94.

FERREIRA A, COSTA RR, DOTTO TS, KERR R, TAVANO VM, BRITO AC, BROTAS V, SECCHI ER \& MENDES CRB. 2020. Changes in Phytoplankton Communities Along the Northern Antarctic Peninsula: Causes, Impacts and Research Priorities. Front Mar Sci 7: 576254.

FRÖLICHER TL, SARMIENTO JL, PAYNTER DJ, DUNNE JP, KRASTING JP \& WINTON M. 2015. Dominance of the Southern Ocean in Anthropogenic Carbon and Heat Uptake in CMIP5 Models. J Clim 28: 862-886.

HENLEY SF ET AL. 2019. Variability and change in the west Antarctic Peninsula marine system: Research priorities and opportunities. Prog Oceanogr 173: 208-237.

HIGGINS HW, WRIGHT SW \& SCHLÜTER L. 2011. Quantitative interpretation of chemotaxonomic pigment data, $p$. 257-313. In: Roy S, Llewellyn CA, Egeland ES \& Johnson G (Eds), Phytoplankton pigments: Characterization, chemotaxonomy and applications in oceanography. Cambridge, UK: Cambridge Univ. Press.

HILLEBRAND H, DÜRSELEN CD, KIRSCHTEL D, POLLINGHER U \& ZOHARY T. 1999. Biovolume calculation for pelagic and benthic microalgae. J Phycol 35: 403-424.

HOLM-HANSEN O \& MITCHELL BG. 1991. Spatial and temporal distribution of phytoplankton and primary production in the western Bransfield Strait region. Deep- Sea Res Part I 38: 961-980.

HOOKER SB ET AL. 2005. The second sea-WiFS HPLC analysis round-robin experiment (SeaHARRE-2). NASA Tech. Memo. 2005-212785. Greenbelt, MD: NASA Goddard space Flight Center. 
HUOT Y, BABIN M, BRUYANT F, GROB C, TWARDOWSKI MS \& CLAUSTRE H. 2007. Relationship between photosynthetic parameters and different proxies of phytoplankton biomass in the subtropical ocean. Biogeosciences 4: 853-868.

JEFFREY SW, MANTOURA RFC \& WRIGHT SW. 1997. Phytoplankton pigments in oceanography: Guidelines to modern methods. Paris: UNESCO.

KERR R, MATA MM, MENDES CRB \& SECCHI ER. 2018. Northern Antarctic Peninsula: A marine climate hotspot of rapid changes on ecosystems and ocean dynamics. Deep- Sea Res Part II 149: 4-9.

KOZLOWSKI WA, DEUTSCHMAN D, GARIBOTTII, TREES C \& VERNET M. 2011. An evaluation of the application of CHEMTAX to Antarctic coastal pigment data. Deep-Sea Res Part I 58: 350-364.

KUCZYNSKA P, JEMIOLA-RZEMINSKA M \& STRZALKA K. 2015. Photosynthetic Pigments in Diatoms. Mar Drugs 13: 5847-5881.

LUND JWG, KIPLING C \& LE CREN ED. 1958. The inverted microscope method of estimating algal numbers and the statistical basis of estimations by counting. Hydrobiologia 11: 143-170.

MACKEY MD, MACKEY DJ, HIGGINS HW \& WRIGHT SW. 1996. CHEMTAX-A program for estimating class abundances from chemical markers: Application to HPLC measurements of phytoplankton. Mar Ecol Prog Ser 144: 265-283.

MALVIYA MS ET AL. 2016. Insights into global diatom distribution and diversity in the world's ocean. Proc Natl Acad Sci 113: E1516-E1525.

MENDEN-DEUER S \& LESSARD EJ. 2000. Carbon to volume relationships for dinoflagellates, diatoms, and other protist plankton. Limnol Oceanogr 45: 569-579.

MENDES CR, CARTAXANA P \& BROTAS V. 2007. HPLC determination of phytoplankton and microphytobenthos pigments: Comparing resolution and sensitivity of a C18 and a C8 method. Limnol Oceanogr Methods 5: 363-370.

MENDES CRB, SOUZA MS, GARCIA VMT, LEAL MC, BROTAS $V$ \& GARCIA CAE. 2012. Dynamics of phytoplankton communities during late summer around the tip of the Antarctic Peninsula. Deep-Sea Res Part I 65: 1-14.

MENDES CRB, TAVANO VM, DOTTO TS, KERR R, SOUZA MS, GARCIA CAE \& SECCHI ER. 2018b. New insights on the dominance of cryptophytes in Antarctic coastal waters: A case study in Gerlache Strait. Deep-Sea Res Part II 149: 161-170.
MENDES CRB, TAVANO VM, KERR R, DOTTO TS, MAXIMIANO T \& SECCHI ER. 2018a. Impact of sea ice on the structure of phytoplankton communities in the northern Antarctic Peninsula. Deep-Sea Res Part II 149: 111-123.

MENDES CRB, TAVANO VM, LEAL MC, SOUZA MS, BROTA $\vee$ \& GARCIA CAE. 2013. Shifts in the dominance between diatoms and cryptophytes during three late summers in the Bransfield Strait (Antarctic Peninsula). Polar Biol 36: 537-547.

MONTAGNES DJS, BERGES JA, HARRISON PJ \& TAYLOR FJR. 1994. Estimating carbon, nitrogen, protein, and chlorophyll a from volume in marine phytoplankton. Limnol Oceanogr 39: 1044-1060.

MONTEIRO T, KERR R, ORSELLI IBM \& LENCINA-AVILA JM. 2020. Towards an intensified summer $\mathrm{CO} 2$ sink behaviour in the Southern Ocean coastal regions. Prog Oceanogr 183: 102267.

MONTES-HUGO M, DONEY SC, DUCLOW HW, FRASER W, MARTINSON D, STAMMERJOHN SE \& SCHOFIELD O. 2009. Recent changes in phytoplankton communities associated with rapid regional climate change along the Western Antarctic Peninsula. Science 323: 1470-1473.

PAN BJ, VERNET M, MANCK L, FORSCH K, EKERN L, MASCIONI M, BARBEAU KA, ALMANDOZ GO \& ORONA AJ. 2020. Environmental drivers of phytoplankton taxonomic composition in an Antarctic fjord. Prog Oceanogr 183: 102295.

RODRIGUEZ F, VARELA M \& ZAPATA M. 2002. Phytoplankton assemblages in the Gerlache and Bransfield Straits (Antarctic Peninsula) determined by light microscopy and CHEMTAX analysis of HPLC pigment data. Deep-Sea Res Part II 49: 723-747.

ROUSSEAUX C \& GREGG W. 2014. Interannual variation in phytoplankton primary production at a global scale. Remote Sens 6: 1-19.

ROZEMA PD, VENABLES HJ, VAN DE POLL WH, CLARKE A, MEREDITH MP \& BUMA AGJ. 2017. Interannual variability in phytoplankton biomass and species composition in northern Marguerite Bay (West Antarctic Peninsula) is governed by both winter sea ice cover and summer stratification. Limnol Oceanogr 62: 235-252.

SCHLÜTER L, MфHLENBERG F, HAVSKUM H \& LARSEN S. 2000. The use of phytoplankton pigments for identifying and quantifying phytoplankton groups in coastal areas: testing the influence of light and nutrients on pigment/ chlorophyll a ratios. Mar Ecol Prog Ser 192: 49-63.

SCHOFIELD O, DUCKLOW HW, MARTINSON DG, MEREDITH MP, MOLINE MA \& FRASER WR. 2010. How do polar marine 
ecosystems respond to rapid climate change? Science 328: 1520-1523.

SCHOFIELD O ET AL. 2017. Decadal variability in coastal phytoplankton community composition in a changing West Antarctic Peninsula. Deep-Sea Res Part I 124: 42-54.

SOURNIA A. 1978. Phytoplankton manual. Paris: Muse'um National d'Histoire Naturelle, UNESCO.

STAMMERJOHN SE, MARTINSON DG, SMITH RC, YUAN X \& RIND D. 2008. Trends in Antarctic annual sea ice retreat and advance and their relation to El Niño-Southern Oscillation and Southern Annular Mode variability. J Geophys Res Oceans 113: C03S90.

STAUBER JL \& JEFFREY SW. 1988. Photosynthetic pigments in fifty-one species of marine diatoms. J Phycol 24: 158-172.

STOCKER TF. 2015. The silent services of the world ocean. Science 350: 764-765.

TAKAHASHI T, SWEENEY C, HALES B, CHIPMAN DW, NEWBERGER T, GODDARD JG, IANNUZZI RA \& SUTHERLAND SC. 2012. The changing carbon cycle in the Southern Ocean. Oceanography 25: 26-37.

TRÉGUER P ET AL. 2017. Influence of diatom diversity on the ocean biological carbon pump. Nat Geosci 11: 27-37.

UTERMÖHL H. 1958. Methods of collecting plankton for various purposes are discussed. Mitt Int Ver Theor Angew Limnol 9: 1-38.

VAN LEEUWE MA, VAN SIKKELERUS B, GIESKES WWC \& STEFELS J. 2005. Taxon-specific differences in photoacclimation to fluctuating irradiance in an Antarctic diatom and a green flagellate. Mar Ecol Prog Ser 288: 9-19.

VARELA M, FERNANDEZ E \& SERRET P. 2002. Size-fractionated phytoplankton biomass and primary production in the Gerlache and south Bransfield Straits (Antarctic Peninsula) in Austral summer 1995-1996. Deep-Sea Res Part II 49: 749-768.

WRIGHT SW, ISHIKAWA A, MARCHANT HJ, DAVIDSON AT, VAN DEN ENDEN RL \& NASH GV. 2009. Composition and significance of picophytoplankton in Antarctic waters. Polar Biol 32: 797-808.

ZANNA L, KHATIWALA S, GREGORY JM, ISON I \& HEIMBACH P. 2018. Global reconstruction of historical ocean heat storage and transport. Proc Natl Acad Sci 116: 1126-1131.

ZAPATA M, RODRÍGUEZ F, FRAGA S, BARRA L \& RUGGIERO MV. 2011. Chlorophyll c pigment patterns in 18 species (51 strains) of the genus Pseudo-nitzschia (Bacillariophyceae). J Phycol 47: 1274-1280.

ZAPATA M, RODRÍGUEZ F \& GARRIDO JL. 2000. Separation of chlorophylls and carotenoids from marine phytoplankton: A new HPLC method using a reversed phase c8 column and pyridine-containing mobile phases. Mar Ecol Prog Ser 195: 29-45.

\section{SUPPLEMENTARY MATERIAL}

Table SI. Pigment to chlorophyll a ratios used for CHEMTAX analysis in the Method A. Initial ratios before analysis (input matrix; higher panel), and one example of ratios after analysis (output matrix; lower panel). $\mathrm{Chl}_{\mathrm{c3}}=$ chlorophyll- ${ }_{\mathrm{c} 3}$; Chl- ${ }_{\mathrm{c} 1}=$ chlorophyll-c1; Perid = peridinin; But-Fuco = 19'-butanoyloxyfucoxanthin; Fuco = fucoxanthin; Hex-Fuco = 19'-hexanoyloxyfucoxanthin; Hex-kfuco = 19'-hexanoyloxy-4-ketofucoxanthin; MGDG-Chl c2 = Chl c2-monogalactosyldiacylglycerol ester; Gyro-e = gyroxanthin diester; Allo = alloxanthin; Chl-b = chlorophyll-b; Chl-a = chlorophyll-a.

Table SII. Pigment to chlorophyll a ratios used for CHEMTAX analysis in the Method B. Initial ratios before analysis (input matrix; higher panel), and one example of ratios after analysis (output matrix; lower panel). Chl-c3 = chlorophyll-c3; Perid = peridinin; But-Fuco = 19'-butanoyloxyfucoxanthin; Fuco = fucoxanthin; HexFuco = 19'-hexanoyloxyfucoxanthin; Allo = alloxanthin; Chl- $b=$ chlorophyll- $b$; Chl- $a=$ chlorophyll- $a$

Table SIII. Average carbon biomass ( $\mu g C \cdot \mathrm{L}^{-1}$ ) of diatom genera assigned as chemotaxonomic subgroup type-A during the late spring and summer months (November, January, February, and March) between 2013 and 2016 along the NAP. Standard deviation is showed in parentheses. The asterisk (*) demonstrates carbon biomass values that are lower than 0.01 .

Table SIV. Average carbon biomass ( $\mu \mathrm{gC} . \mathrm{L}^{-1}$ ) of diatom genera assigned as chemotaxonomic subgroup type-B during the late spring and summer months (November, January, February, and March) between 2013 and 2016 along the NAP. Standard deviation is showed in parentheses. The asterisk (*) demonstrates carbon biomass values that are lower than 0.01 .

Figure S1. Relationships between chemotaxonomic subgroups type-A (on the left panel) and type-B (on the right panel) of diatoms ( $\left.\mathrm{mg} \cdot \mathrm{m}^{-3} \mathrm{Chl}-\mathrm{a}\right)$ and their respective carbon biomass values $\left(\mu g C . \mathrm{L}^{-1}\right)$, as the sum of the corresponding identified diatom genera. Figure S2. Relationships of the diatom absolute concentrations (mg. $\mathrm{m}^{-3} \mathrm{Chl}-\mathrm{a}$ ) from the Method A (on the left panel) and from the Method $B$ (on the right panel) with carbon biomass values ( $\left.\mu g C . L^{-1}\right)$, as the total sum of the identified diatom genera.

Figure S3. The lack of statistical relationship between carbon biomass values ( $\mu \mathrm{gC} . \mathrm{L}^{-1}$ ) of the remaining of the most abundant diatom genera and chlorophyll-c3 (Chl-c3; $\left.\mathrm{mg} \cdot \mathrm{m}^{-3}\right)$, represented by dark gray circles at background, and chlorophyll-c1 (Chl-c1; mg.m ${ }^{-3}$ ), which is represented by black open circles. 


\section{How to cite}

COSTA RR, MENDES CRB, SOUZA MS, TAVANO VM \& SECCHI ER. 2022. Chemotaxonomic characterization of the key genera of diatoms in the Northern Antarctic Peninsula. An Acad Bras Cienc 94: e20210584. DOI 10.1590/0001-3765202220210584.

Manuscript received on April 22, 2021;

accepted for publication on August 20, 2021

\section{RAUL RODRIGO COSTA}

https://orcid.org/0000-0002-0940-3565

\section{CARLOS RAFAEL B. MENDES}

https://orcid.org/0000-0001-6875-8860

\section{MÁRCIO S. DE SOUZA}

https://orcid.org/0000-0003-1572-9307

\section{VIRGINIA MARIA TAVANO}

https://orcid.org/0000-0003-0039-8111

\section{EDUARDO R. SECCHI}

https://orcid.org/0000-0001-9087-9909

Universidade Federal do Rio Grande (FURG), Instituto de

Oceanografia, Av. Itália, Km 8, 96203-900 Rio Grande, RS, Brazil

Correspondence to: Raul Rodrigo Costa

E-mail: raul_rodrigoc@hotmail.com

\section{Author Contributions}

R.R.C. contributed to the conception of this work, writing the first draft and designing the figures of the manuscript. R.R.C. and C.R.B.M. carried out the HPLC/CHEMTAX analysis. M.S.S. performed the microscopic analysis. C.R.B.M., M.S.S, V.M.T., and E.R.S. contributed to the organization and writing of the final version of the manuscript. All authors contributed to manuscript revision, read, and approved the submitted version.

\section{(cc) BY}

